\title{
Aplikasi Pengolahan Data Statistik Sektoral pada Dinas Komunikasi dan Informatika Provinsi Kalimantan Barat
}

\author{
Dara Nadinda ${ }^{\text {a1 }}$, Heri Priyanto ${ }^{\mathrm{a} 2}$, Hafiz Muhardi ${ }^{\mathrm{a} 3}$ \\ aProgram Studi Informatika Fakultas Teknik Universitas Tanjungpura \\ Jl. Prof. Dr. H. Hadari Nawawi, Kota Pontianak, 78115 \\ ${ }^{1}$ daranadinda. dn agmail. com \\ ${ }^{2}$ heripriyanto.stmtegmail. com \\ ${ }^{3}$ hmuhardi dgmail.com
}

\begin{abstract}
Abstrak
Penelitian ini menjelaskan bagaimana membangun aplikasi pengolahan data statistik sektoral yang bertujuan untuk mengumpulkan, mengolah dan mempublikasikan data statistik sektoral dilingkungan pemerintahan Provinsi Kalimantan Barat. Statistik sektoral sebagai data yang digunakan dalam penelitian merupakan jenis statistik yang pemanfaatannya ditujukan untuk memenuhi kebutuhan instansi pemerintah tertentu dalam rangka penyelenggaraan tugas-tugas pemerintah dan tugas pembangunan yang merupakan tugas pokok instansi pemerintah yang bersangkutan. Instansi pemerintah yang dimaksud adalah Dinas Komunikasi dan Informatika Provinsi Kalimantan Barat, khususnya Seksi Statistik pada Bidang Persandian dan Statistik. Namun dalam proses pengumpulan data statistik sektoral yang diperlukan mengalami beberapa kendala, khususnya memakan terlalu banyak waktu. Untuk mengatasi kendala tersebut, maka dirancanglah Aplikasi Pengolahan Data Statistik Sektoral pada Dinas Komunikasi dan Informatika Provinsi Kalimantan Barat. Data statistik sektoral yang digunakan pada penelitian ini adalah sebanyak 70 baris data. Pengujian menggunakan metode Black-Box mendapatkan hasil bahwa implementasi dan fungsi aplikasi telah bekerja dengan baik sesuai dengan perancangan. Pengujian yang dilakukan dengan cara wawancara untuk menguji tingkat penerimaan pengguna atau user acceptance testing yang dilakukan kepada kepala seksi statistik, bidang persandian dan statistik, Dinas Komunikasi dan Informatika provinsi Kalimantan Barat menyatakan bahwa aplikasi yang dibangun telah sesuai dengan yang diharapkan.
\end{abstract}

Kata kunci: Data Statistik Sektoral, Instansi Pemerintahan Provinsi, Organisasi Perangkat Daerah, Metode BlackBox, User Acceptance Testing

\section{Application of Sectoral Statistical Data Processing at the Office of Communication and Information of West Borneo Province}

\begin{abstract}
This study explains how to develop sectoral statistical data processing applications that aim to collect, process, and publish sectoral statistical data in the government environment of West Borneo Province. Sectoral statistics as data used in research are types of statistics whose use is intended to meet the needs of certain government agencies in the context of carrying out government tasks and development tasks, which are the main tasks of the relevant government agencies. The government agency in question is the Office of Communication and Information of the Province of West Borneo, particularly the Statistics Section in the Field of Encoding and Statistics. However, in the process of collecting sectoral statistical data that is required to experience several obstacles, in particular, it takes too much time. To overcome this obstacle, the Sectoral Statistical Data Processing Application was designed at the West Borneo Province Communication and Information Office. Sectoral statistical data used in this study were 70 data rows. Tests using the Black-Box method get the results that the implementation and application functions have worked well by design. Tests conducted by way of interviews to test the level of user acceptance or user acceptance testing conducted to the head of the statistics section, coding, and statistics, the Department of Communication and Information of the province of West Borneo stated that the application was built as expected.
\end{abstract}

Keywords: Sectoral Statistical Data, Provincial Government Agencies, Regional Apparatus Organizations, BlackBox Method, User Acceptance Testing 


\section{Pendahuluan}

Seiring dengan makin pesatnya perkembangan aplikasi perangkat lunak komputer dan internet, maka manajemen dan penyebaran informasi akan menjadi lebih efektif dan efisien. Sehingga menyebabkan banyak perusahaan/instansi yang memanfaatkan peluang ini untuk mengelola dan menyebarluaskan informasi dengan dukungan dari aplikasi perangkat lunak komputer yang dapat diakses melalui jaringan internet. Aplikasi merupakan program yang berisikan perintah-perintah untuk melakukan pengolahan data. Jadi aplikasi secara umum adalah suatu proses dari cara manual yang ditransformasikan ke komputer dengan membuat sistem atau program agar data diolah lebih berdaya guna secara optimal. Salah satu instansi di lingkungan pemerintahan Kalimantan Barat yang ingin memanfaatkan aplikasi perangkat lunak komputer dan internet adalah Dinas Komunikasi dan Informatika Kalimantan Barat.

Dinas Komunikasi dan Informatika (DISKOMINFO) Kalimantan Barat adalah sebuah instansi pemerintahan yang mempunyai tugas melaksanakan kewenangan daerah dibidang pengelolaan Teknologi Informasi dan Komunikasi di lingkungan pemerintahan provinsi Kalimantan Barat. Dalam pelaksanaannya, Dinas Komunikasi dan Informatika dibagi menjadi bidangbidang sesuai dengan kebutuhan. Salah satu bidang yang dibentuk adalah bidang persandian dan statistik. Bidang ini bertanggung jawab untuk mengelola data dan informasi yang berhubungan dengan persandian dan statistik demi tersedianya layanan data dan informasi untuk menunjang pelaksanaan dan pembangunan daerah provinsi. Layanan data dan informasi yang sebelumnya telah dikumpulkan Dinas Komunikasi dan Informatika, khususnya bidang statistik kemudian perlu untuk diolah dan didistribusikan ke berbagai instansi di lingkungan pemerintahan provinsi Kalimantan Barat. Agar proses pengolahan dan distribusi dapat berlangsung dengan lebih cepat dan tepat, maka diperlukanlah sebuah media untuk menunjang hal tersebut.

Untuk menciptakan media yang mampu menunjang pengolahan dan distribusi data statistik sektoral, maka akan dirancang dan dibangun sebuah Aplikasi yang diberi nama Aplikasi Pengolahan Data Statistik Sektoral Pada Dinas Komunikasi dan Informatika Provinsi Kalimantan Barat. Aplikasi Pengolahan Data Statistik Sektoral ini dibangun untuk digunakan sebagai aplikasi yang mampu mengolah dan mendistribusikan data serta informasi yang berhubungan dengan statistik dari berbagai instansi pemerintahan di Kalimantan Barat. Sistem Informasi ini diharapkan mampu mewadahi, sesuai dengan fungsinya sebagai statistik sektoral, yaitu untuk memenuhi kebutuhan instansi pemerintahan sektor (regional) tertentu dalam rangka penyelenggaraan tugas-tugas pemerintah dan tugas pembangunan yang merupakan tugas pokok instansi bersangkutan.

Aplikasi yang akan dibangun adalah sebuah sistem untuk mengolah dan mendistribusikan data dan informasi statistik dari berbagai instansi pemerintahan yang dikelola oleh Dinas Komunikasi dan Informatika Kalimantan Barat Khusus untuk memasukkan data ke dalam aplikasi ini, Sistem ini dapat diakses oleh yang berkepentingan dan memiliki otoritas dalam hal input data.

\section{TINJAUAN PUSTAKA}

\section{A. Penelitian Terkait}

Beberapa penelitian terdahulu yang digunakan sebagai acuan penelitian salah satunya yaitu penelitian mengenai CAPI (Computer Assisted Personal Interviewing) yaitu pengumpulan informasi menggunakan media komputer untuk mengumpulkan data kor Survei Sosial-Ekonomi Nasional (SUSENAS). Hasil dari penelitian ini adalah sebuah prototipe sistem Aplikasi CAPI Pengumpulan Data Kor Susenas yang terdiri atas 3 komponen yaitu, Aplikasi Desktop Pengawas, Aplikasi Desktop Pencacah dan Aplikasi Web Monitoring. Aplikasi ini dirancang berdasarakan permasalahan yang terdiri atas, kebutuhan biaya yang besar apabila sistem dilakukan dengan sistem PAPI (Paper and Pen Interviewing), Proses pengumpulan data yang lama dan kesulitan perbaikan apabila ada kesalahan karena harus memanggil responden kembali untuk pengisian data ulang. Bagian yang dijadikan referensi pada penelitian ini adalah tentang pengumpulan data dan informasi menggunakan komputer atau penggunaan sistem CAPI. Pengujian pada penelitian ini menggunakan metode Black-Box untuk menguji bahwa tidak ditemukan kesalahan pada sistem dan kuesioner SUS (System Usability Scale) untuk evaluasi antarmuka [1].

Selain itu, penelitian mengenai Rancang Bangun Aplikasi Pelaporan Dana Alokasi Khusus Berbasis Web yang dapat membantu Sub Bidang Monitoring dan Pelaporan dalam penerimaan laporan Dana Alokasi Khusus pada Badan Perancanaan Pembangunan Daerah Provinsi Sulawesi Utara. Hasil dari penelitian ini adalah sebuah Aplikasi Pelaporan Dana Alokasi Khusus Berbasis Web dengan 2 jenis pengguna yaitu admin yang dapat menerima laporan yang dikirim oleh staf BAPPEDA Kabupaten/Kota dan staf Bappeda Kabupaten/Kota dapat membuat dan mengirim laporan DAK kepada admin. Bagian yang dijadikan referensi pada penelitian ini adalah tentang alur pengumpulan data yang dilakukan melalui aplikasi perangkat lunak berbasis web. Pengujian pada penelitian ini menggunakan metode Black-Box untuk menguji bahwa tidak ditemukan kesalahan pada system [2] .

\section{B. Statistik Sektoral}

Statistik Sektoral adalah statistik yang pemanfaatannya ditujukan untuk memenuhi kebutuhan instansi pemerintah tertentu dalam rangka penyelenggaraan tugas-tugas 
pemerintah dan tugas pembangunan yang merupakan tugas pokok instansi pemerintah yang bersangkutan [3].

\section{Aplikasi}

Aplikasi merupakan penggunaan dalam suatu komputer, instruksi (instruction) atau pernyataan (statement) yang disusun sedemikian rupa sehingga komputer dapat memproses input menjadi output [4].

\section{Flowchart}

Flowchart atau bagan alir adalah bagan (chart) yang menunjukkan alir (flow) didalam program atau prosedur sistem secara logika. Bagan alir (flowchart) yang digunakan terutama untuk alat bantu komunikasi dan untuk dokumentasi [5].

\section{E. Unified Modelling Language}

Unified Modelling Language (UML) adalah sebuah teknik pengembangan sistem yang menggunakan bahasa grafis sebagai alat untuk pendokumentasian dan spesifikasi pada sistem[6].

\section{F. Basis Data}

Basis data adalah kumpulan data yang saling berhubungan secara logis dan didesain untuk mendapatkan data yang dibutuhkan oleh suatu organisasi [7].

\section{G. $S Q L$}

SQL (Structured Query Language) adalah bahasa yang digunakan untuk mengelola data pada RDBMS [8].

\section{H. $M y S Q L$}

MySQL adalah sistem manajemen database SQL yang bersifat Open Source dan paling populer saat ini. Sistem database MySQL mendukung beberapa fitur seperti multithreaded, multi-user, dan SQL database management system (DBMS) [9].

\section{HTML}

HTML (Hyper Text Markup Language) merupakan bahasa pemrograman web yang memberitahukan peramban web (web browser) bagaimana menyusun dan menyajikan konten di halaman web [10].

\section{J. $P H P$}

PHP: Hypertext Preprocessor atau disingkat dengan PHP ini adalah suatu bahasa scripting khususnya digunakan untuk web development. Karena sifatnya yang server side scripting, maka untuk menjalankan PHP harus menggunakan web server [11].

\section{K. Laravel}

Laravel dirilis dibawah lisensi MIT dengan kode sumber yang sudah disediakan oleh Github, sama seperti framework-framework yang lain, Laravel dibangun dengan konsep MVC (Model-Controller-View), kemudian Laravel dilengkapi juga command line tool yang bernama "Artisan" yang bisa digunakan untuk packaging bundle dan instalasi bundle melalui command prompt [12].

\section{Black Box Testing}

Black Box Testing befokus pada spesifikasi fungsional dari perangkat lunak, kumpulan kondisi input dan melakukan pengetesan pada fungsional program [13].

\section{User Acceptance Testing}

User Acceptance Testing merupakan pengujian yang dilakukan oleh end-user dimana user tersebut adalah sta f/karyawan perusahaan yang langsung berinteraksi dengan sistem dan dilakukan verifikasi apakah fungsi yang ada telah berjalan sesuai dengan kebutuhan/fungsinya[14]

\section{METODOLOGI PENELITIAN}

\section{A. Data Penelitian}

Data penelitian berupa data statistik sektoral yang berasal dari organisasi perangkat daerah di lingkungan pemerintah provinsi Kalimantan Barat. Data yang dimaksud merupakan data berbentuk angka atau bilangan asli yang nantinya akan diubah menjadi bentuk lain.

\section{B. Alat Penelitian}

Perangkat penelitian yang digunakan dalam penelitian ini terdiri dari perangkat keras dan perangkat lunak. Adapun perangkat yang digunakan diantaranya, yaitu perangkat keras Laptop Asus A456U dengan spesifikasi Prosesor Intel Core i5-6200U , Ram DDR 4GB dan LCD 14" HD LED LCD. Perangkat lunak yang digunakan dalam penelitian ini adalah, Sistem Operasi Windows 10 Pro 64 Bit, Sublime Text 3, Xampp Version 5.6.35, Laravel Framework 5.4.3 dan Browser Google Chrome.

\section{Metode Penelitian}

Adapun langkah-langkah pada metode penelitian diberikan Gambar 1. Diagram Alir Penelitian. Metode penelitian diawali dengan studi literatur, analisis kebutuhan, pengumpulan data, perancangan sistem, pembuatan dan implementasi sistem, pengujian sistem, analisis hasil pengujian, dan penarikan kesimpulan.

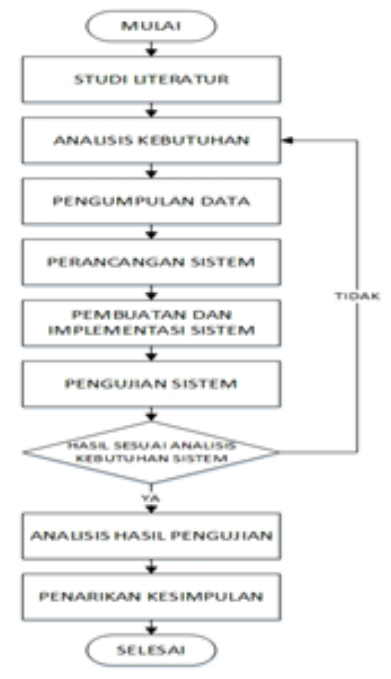

Gambar 1. Diagram Alir Penelitian 


\section{Analisis Kebutuhan}

Analisis kebutuhan merupakan langkah awal untuk menentukan gambaran perangkat yang akan dihasilkan ketika pengembang melaksanakan sebuah proyek pembuatan perangkat lunak. Tindakan awal yang dilakukan untuk memenuhi analisis kebutuhan terhadap aplikasi yang akan dibangun adalah melakukan observasi atau pengamatan pada cara kerja statistik sektoral menurut seksi statistik, bidang persandian dan statistik, Dinas Komunikasi dan Informatika. Seksi Statistik pada Dinas Komunikasi dan Informatika bertugas sebagai wali data statistik sektoral, maksudnya yaitu memiliki kewenangan untuk mengumpulkan kemudian mempublikasikan data statistik sektoral dilingkungan pemerintah.

Menurut jenisnya, Statistik terbagi menjadi 3 jenis, yaitu Statistik Sektoral, Statistik Dasar dan Statistik Khusus. Statistik Sektoral adalah statistik yang pemanfaatannya ditujukan untuk memenuhi kebutuhan instansi pemerintah tertentu dalam rangka penyelenggaraan tugas-tugas pemerintah dan tugas pembangunan yang merupakan tugas pokok instansi pemerintah yang bersangkutan. Statistik Dasar adalah statistik yang pemanfaatannya ditujukan untuk keperluan yang bersifat luas, baik pemerintah maupun masyarakat. Penyelenggaraannya menjadi tanggung jawab BPS. Sedangkan, Statistik Khusus adalah statistik yang pemanfaatannya ditujukan untuk memenuhi kebutuhan internal dari suatu instansi/perusahaan swasta dalam rangka penyelenggaraan riset atau penelitian. Berdasarkan uraian mengenai jenis statistik diatas, yang menjadi kewenangan pemerintah daerah adalah statistik sektoral [15].

Untuk pemerintah daerah, statistik sektoral berfungsi sebagai sumber data demi mendukung penyelenggaraan tugas-tugas pemerintahan dan tugas-tugas pembangunan daerah. Data-data statistik sektoral ini berasal dari organisasi-organisasi perangkat daerah di lingkungan pemerintahan daerah, dalam hal ini adalah Pemerintah Daerah Provinsi Kalimantan Barat. Organisasi perangkat daerah merupakan organisasi atau lembaga pada pemerintah daerah yang bertanggung jawab kepada kepala daerah dalam rangka penyelenggaraan pemerintahan di daerah. Organisasi-organisasi ini memiliki tugas pokok dan fungsi masing-masing dalam pelaksanaannya. Namun, terdapat jenis-jenis tugas dan fungsi tertentu yang saling berhubungan antara OPD satu dengan yang lainnya. Hal ini menyebabkan data statistik sektoral tertentu yang dimiliki masing-masing OPD saling beririsan. Sebagai contoh, yaitu data statistik sektoral mengenai angka jumlah wisatawan milik Organisasi Perangkat Daerah Dinas Pariwisata dan Ekonomi Kreatif yang berhubungan dengan angka jumlah penumpang angkutan udara milik Organisasi Perangkat Daerah Dinas Perhubungan. Apabila data-data tersebut dianalisis maka kemudian dapat ditarik kesimpulan mengenai pengembangan lokasi wisata oleh Dinas Pariwisata dan Ekonomi Kreatif. Untuk itu, datadata sektoral yang berhubungan tersebut dapat diklasifikasikan menjadi klasisfikasi tertentu. Berdasarkan sumber data sebanyak 70 jenis data yang telah dikumpulkan oleh Dinas Komunikasi dan Informatika provinsi Kalimantan Barat, khususnya seksi statistik kemudian dapat diklasifikasikan menjadi 3 jenis data berdasarkan waktu dan tempat, yaitu data statistik sektoral berdasarkan tahun, data statistik sektoral berdasarkan bulan dan data statistik sektoral berdasakan kabupaten/kota. Selain itu, data-data tersebut juga dapat diklasifikasikan menjadi 19 jenis klasifikasi. Klasifikasiklasifikasi tersebut ditunjukkan pada tabel 1.

TABEL I

KLASIFIKASI JENIS DATA STATISTIK SEKTORAL

\begin{tabular}{|c|l|}
\hline No & \multicolumn{1}{|c|}{ Klasifikasi } \\
\hline 1. & Wilayah \\
\hline 2. & Kependudukan \\
\hline 3. & Perkebunan \\
\hline 4. & Pariwisata \\
\hline 5. & Pembangunan \\
\hline 6. & Perhubungan \\
\hline 7. & Pangan \\
\hline 8. & Kesehatan \\
\hline 9. & Pendapatan \\
\hline 10. & Tenaga Kerja \\
\hline 11. & Lingkungan \\
\hline 12. & Sosial \\
\hline 13. & Koperasi \\
\hline 14. & Energi \\
\hline 15. & Pendidikan \\
\hline 16. & Perikanan \\
\hline 17. & Komunikasi \\
\hline 18. & Bencana Daerah \\
\hline 19. & Kehutanan \\
\hline
\end{tabular}

Data-data statistik sektoral yang telah diklasifikasikan tersebut kemudian dapat disimpan dan diubah menjadi grafik. Grafik yang ditampilkan dibagi menjadi 3 jenis, yaitu grafik batang, grafik garis dan grafik pie berdasarkan 3 jenis data sebelumnya. Selanjutnya apabila organisasi perangkat daerah memerlukan data-data tertentu, maka OPD dapat menghubungi seksi statistik pada Dinas Komunikasi dan Informatika Provinsi Kalimantan Barat.

Secara umum, alur sistem yang sedang berjalan pada proses pengumpulan, pengolahan dan pendistribusian data statistik sektoral adalah sebagai berikut.

1) Seksi Statistik pada Diskominfo meminta data statistik sektoral kepada organisasi perangkat daerah yang bersangkutan.

2) Organisasi perangkat daerah kemudian memberikan data statistik sektoral sesuai permintaan Diskominfo.

3) Setelah diterima oleh Diskominfo, data statistik sektoral kemudian diolah sesuai kebutuhan Diskominfo.

4) Apabila organisasi perangkat daerah memerlukan data statistik sektoral mengenai jenis tertentu, maka organisasi perangkat daerah kemudian meminta kembali kepada Diskominfo. 
Berdasarkan uraian diatas, maka penulis melakukan wawancara kepada Kepala Seksi Statistik, Bidang Persandian dan Statistik, Dinas Komunikasi dan Informatika Provinsi Kalimantan Barat. Wawancara yang dilakukan digunakan untuk mengumpulkan data dan informasi mengenai kebutuhan pengguna akan aplikasi yang akan dibangun, khususnya digunakan untuk mengumpulkan informasi mengenai tujuan, target pengguna, alur kerja pengumpulan data, kendala yang dialami saat ini dan alur sistem yang sedang berjalan.

Berdasarkan hasil dari wawancara tersebut, maka analisis kebutuhan terhadap aplikasi yang dibangun berdasarkan aspek rekayasa perangkat lunak dapat dirangkum sebagai berikut.

1) Aplikasi statistik sektoral yang akan dibangun harus mampu memenuhi tujuannya yaitu mengumpulkan data statistik sektoral dari berbagai organisasi perangkat daerah dilingkungan pemerintahan provinsi Kalimantan Barat yang kemudian akan ditampilkan di dalam situs web.

2) Target pengguna aplikasi yang akan dibangun dibagi menjadi 3 , yaitu administrator, admin OPD dan guest.

3) Alur pengumpulan data statistik sektoral pada aplikasi yang akan dibangun sama dengan proses manual namun difasilitasi oleh form-form khusus yang disediakan nantinya dan bersifat paperless.

4) Kendala-kendala yang dihadapi pada proses manual seperti keterbatasan waktu dan keabsenan petugas diharapkan dapat diatasi pada proses terkomputerisasi.

5) Alur pada aplikasi yang akan dibangun menyesuaikan dengan alur sistem yang sedang berjalan saat ini.

\section{E. Arsitektur Sistem}

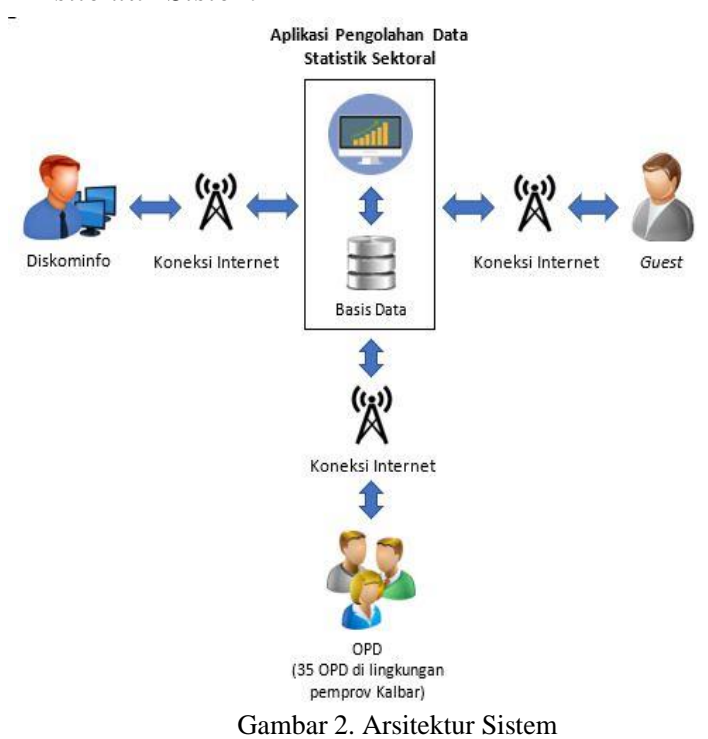

Arsitektur sistem pada Gambar 2 dijelaskan sebagai berikut :
1) Administrator memerlukan koneksi internet untuk mengakses admin panel agar dapat melakukan kelola data. Adapun data yang dikelola adalah data statistik sektoral yang berasal dari seluruh organisasi perangkat daerah di lingkungan provinsi Kalimantan Barat dan semua data yang perlu ditampilkan pada halaman utama sistem informasi. Data yang dikelola kemudian akan disimpan di database.

2) Admin OPD memiliki halaman sendiri untuk melakukan kelola data (Admin OPD Panel). Untuk mengakses halaman tersebut, admin OPD memerlukan koneksi internet. Adapun data yang akan dikelola adalah data statistik sektoral dan data profil sesuai dengan instansi Admin OPD tersebut bernaung.

3) Guest hanya dapat mengakses halaman sistem informasi. Adapun halaman ini memiliki url yang berbeda dengan halaman Administrator maupun Admin OPD. Setelah diakses, maka akan ditampilkan halaman utama sistem informasi. Data yang ditampilkan pada halaman utama sistem informasi berasal dari database.

\section{F. Desain Sistem}

\section{1) Use Case Diagram}

Use case diagram atau diagram use case merupakan pemodelan untuk kelakukan (behavior) sistem informasi yang akan dibuat. Use case mendeskripsikan sebuah interaksi antara satu atau lebih aktor dengan sistem informasi yang akan dibuat [16]. Berikut merupakan use case diagram sistem yang dapat dilihat pada Gambar 3.

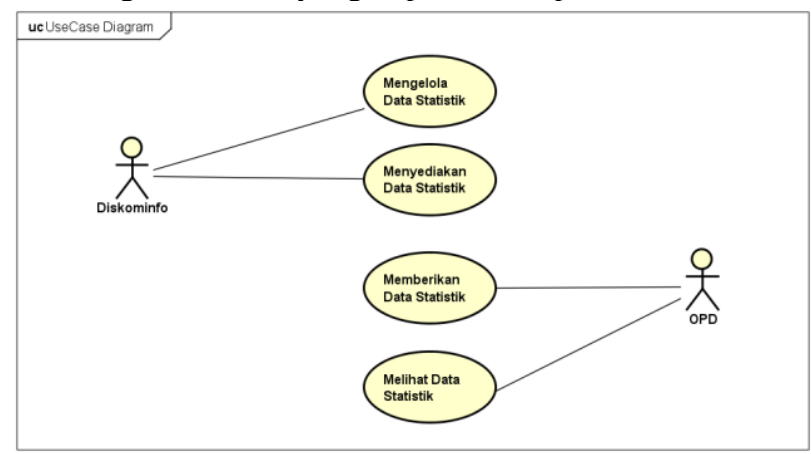

Gambar 3. Use Case Diagram Sistem 


\section{2) Class Diagram} pkg Class Diagraml

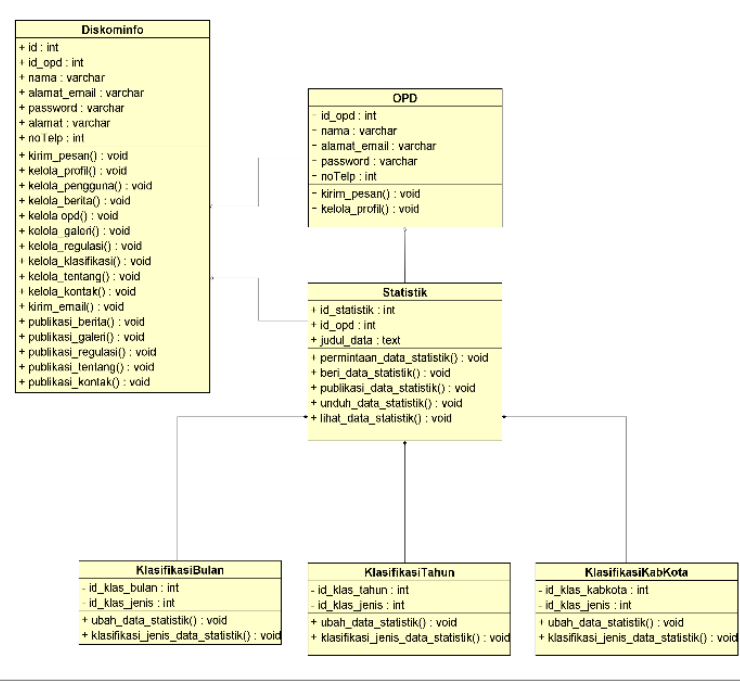

Gambar 4. Class Diagram Sistem

\section{HASIL DAN ANALISIS}

Pada bab ini akan dilakukan implementasi dan hasil pengujian terhadap aplikasi. Tahapan ini dilakukan setelah perancangan sistem selesai dan selanjutnya akan diimplementasikan kemudian dilakukan pengujian terhadap aplikasi. Implementasi dan hasil pengujian yang dilakukan untuk mengetahui aplikasi tersebut dapat berjalan sesuai dengan tujuannya atau tidak.

\section{A. Implementasi}

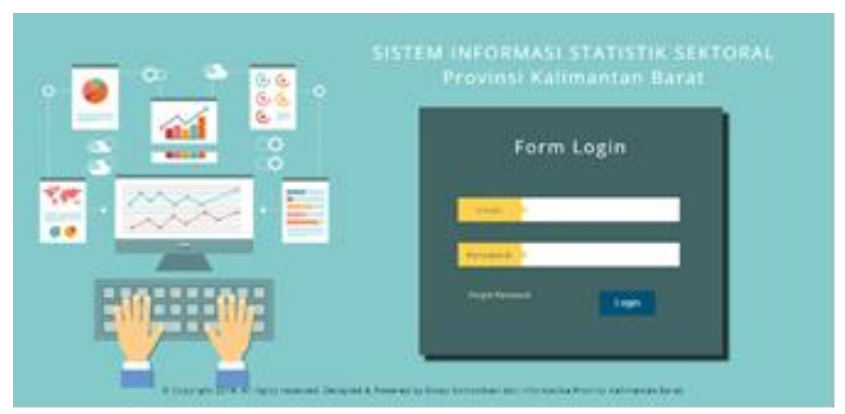

Gambar 5. Antarmuka Halaman Login

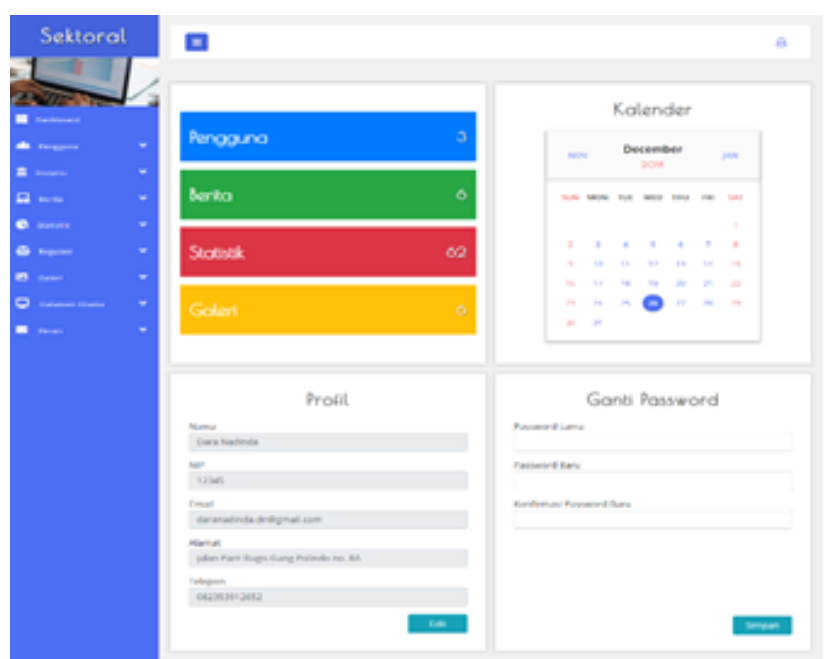

Gambar 6. Antarmuka Halaman Dashboard Administrator

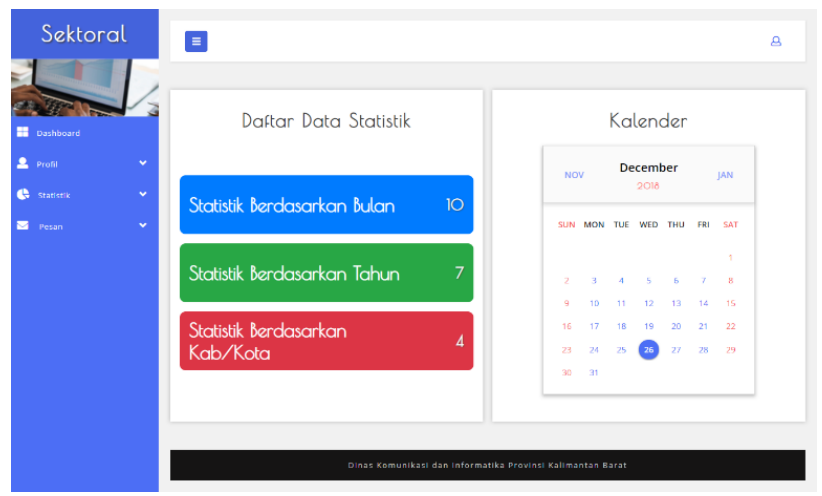

Gambar 7. Antarmuka Halaman Dashboard Admin OPD
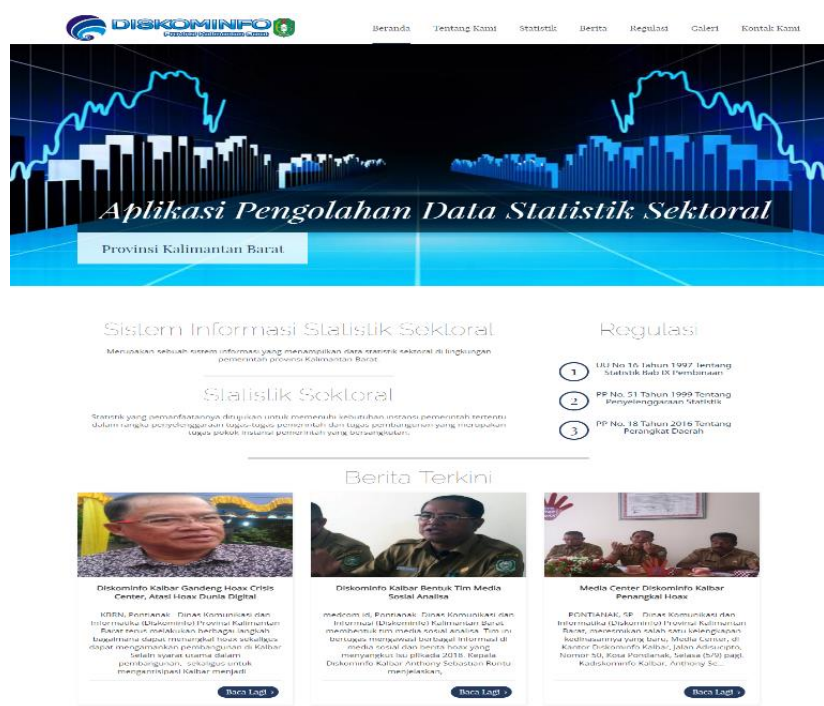

Gambar 8. Antarmuka Halaman Utama

\section{B. Pengujian Black-Box}

Pengujian black-box pada penelitian ini terdiri pengujian login. 
TABEL II

HASIL PENGUJIAN LOGIN

\begin{tabular}{|c|c|c|c|c|}
\hline $\begin{array}{c}\text { Masukan } \\
\text { (Input) }\end{array}$ & \multicolumn{2}{|c|}{ Contoh Data } & $\begin{array}{c}\text { Hasil } \\
\text { Eksekusi }\end{array}$ & Keterangan \\
\hline \multirow[t]{2}{*}{ Data Null } & Email & & \multirow{2}{*}{$\begin{array}{l}\text { Tidak } \\
\text { dieksekusi }\end{array}$} & \multirow{2}{*}{$\begin{array}{l}\text { Muncul } \\
\text { pesan: } \\
\text { "Silahkan isi } \\
\text { kolom ini." }\end{array}$} \\
\hline & Password & & & \\
\hline \multirow[t]{2}{*}{$\begin{array}{l}\text { Data yang } \\
\text { benar }\end{array}$} & Email & $\begin{array}{l}\text { statistik } \\
\text { sektoral. } \\
\text { kalbar } \\
\text { @gmail. } \\
\text { com }\end{array}$ & \multirow[t]{2}{*}{ Dieksekusi } & \multirow[t]{2}{*}{$\begin{array}{l}\text { Masuk ke } \\
\text { halaman } \\
\text { admin } \\
\text { panel }\end{array}$} \\
\hline & Password & $\begin{array}{l}\text { sandi } \\
\text { admin }\end{array}$ & & \\
\hline \multirow[t]{2}{*}{$\begin{array}{l}\text { Data yang } \\
\text { benar }\end{array}$} & Email & $\begin{array}{l}\text { sektoral. } \\
\text { dinsos } \\
@ \text { gmail. } \\
\text { com }\end{array}$ & \multirow[t]{2}{*}{ Dieksekusi } & \multirow[t]{2}{*}{$\begin{array}{l}\text { Masuk ke } \\
\text { halaman } \\
\text { admin } \\
\text { OPD panel }\end{array}$} \\
\hline & Password & $\begin{array}{l}\text { sandi } \\
\text { OPD }\end{array}$ & & \\
\hline \multirow[t]{2}{*}{$\begin{array}{l}\text { Data yang } \\
\text { salah }\end{array}$} & Email & $\begin{array}{l}\text { example- } \\
\text { salah } \\
@ \text { gmail. } \\
\text { com }\end{array}$ & \multirow[t]{2}{*}{$\begin{array}{l}\text { Tidak } \\
\text { dieksekusi }\end{array}$} & \multirow{2}{*}{$\begin{array}{l}\text { Muncul } \\
\text { pesan: } \\
\text { "Password } \\
\text { atau } \\
\text { Email salah." }\end{array}$} \\
\hline & Password & $\begin{array}{l}\text { example- } \\
\text { salah }\end{array}$ & & \\
\hline
\end{tabular}

Hasil pengujian Input Data Statistik ditunjukkan pada tabel 3 .

TABEL III

HASIL PENGUJIAN INPUT DATA STATISTIK

\begin{tabular}{|c|c|c|c|c|}
\hline$\underset{\text { Masukan }}{\text { (Input) }}$ & \multicolumn{2}{|c|}{ Contoh Data } & $\begin{array}{c}\text { Hasil } \\
\text { Eksekusi }\end{array}$ & $\begin{array}{c}\text { Keterang } \\
\text { an }\end{array}$ \\
\hline \multirow{12}{*}{$\begin{array}{l}\text { Data yang } \\
\text { benar }\end{array}$} & Instansi & Disdukcapil & \multirow[t]{12}{*}{ Dieksekusi } & \multirow{12}{*}{$\begin{array}{l}\text { Masuk ke } \\
\text { halaman } \\
\text { daftar } \\
\text { statistik. } \\
\text { Muncul } \\
\text { pesan: } \\
\text { "Berhasil } \\
\text { Menambah } \\
\text { kan Data!" }\end{array}$} \\
\hline & Judul & $\begin{array}{l}\text { Angka } \\
\text { Kematian } \\
\text { Tahun } \\
\text { 2014-2018 }\end{array}$ & & \\
\hline & Tahun & 2014 & & \\
\hline & Nilai & 21 & & \\
\hline & Tahun & 2015 & & \\
\hline & Nilai & 33 & & \\
\hline & Tahun & 2016 & & \\
\hline & Nilai & 67 & & \\
\hline & Tahun & 2017 & & \\
\hline & Nilai & 34 & & \\
\hline & Tahun & 2018 & & \\
\hline & Nilai & 24 & & \\
\hline
\end{tabular}

\begin{tabular}{|l|l|l|l|l|}
\hline & Deskripsi & Menggamb & & \\
arkan & & & \\
tentang data & & \\
statistik & & & \\
& kematian & & \\
& pada tahun & & \\
& 2014-2018 & & \\
& di & & \\
& Kalimantan & & \\
& Barat & & \\
\hline
\end{tabular}

\section{User Acceptance Testing (UAT)}

Pengujian UAT adalah suatu proses pengetesan untuk melihat sejauh mana aplikasi atau sistem yang dibangun dapat digunakan dan sesuai dengan kebutuhan pengguna. Pengujian dengan UAT dilakukan dengan mengajukan beberapa pertanyaan terhadap Kepala Seksi Statistik, Dinas Komunikasi dan Informatika yang bertindak sebagai pengguna. Pada penelitian ini, responden yang terlibat berjumlah 1 orang yang merupakan pengguna langsung dari aplikasi pengolahan data statistik sektoral yang dibangun.

Beberapa pertanyaan disusun untuk melihat tingkat kesesuaian sistem terhadap keinginan pengguna. Pertanyaan-pertanyaan tersebut antara lain terkait dengan aspek kegunaan dan kemudahan akan aplikasi atau sistem yang dibangun. Berdasarkan pertanyaan-pertanyaan yang telah diajukan, maka jawaban yang dihasilkan dapat dirangkum sebagai berikut.

1) Aplikasi statistik sektoral yang akan dibangun mampu memenuhi tujuannya yaitu mengumpulkan data statistik sektoral dari berbagai organisasi perangkat daerah dilingkungan pemerintahan provinsi Kalimantan Barat yang kemudian akan ditampilkan di dalam situs web.

2) Level dan fungsi masing-masing pengguna yang dapat diakomodir oleh aplikasi statistik sektoral sudah sesuai.

3) Kebutuhan akan data statistik sektoral mampu dipenuhi oleh aplikasi yang dibangun.

4) Kendala-kendala yang dihadapi pada proses manual seperti keterbatasan waktu dan keabsenan petugas dapat diatasi menggunakan aplikasi yang dibangun.

5) Proses yang berjalan secara manual telah sesuai dengan aplikasi yang dibangun.

6) Produk yang dihasilkan oleh sistem dianggap telah sesuai, yaitu menghasilkan grafik berbentuk gambar dan berkas excel berdasarkan data statistik sektoral yang berasal dari organisasi perangkat daerah. 
7) Respon aplikasi terhadap input yang dilakukan dianggap cukup memuaskan dan sesuai.

8) Kinerja pada saat administrator melakukan proses olah data telah sesuai dan mudah dimengerti.

9) Kinerja pada saat admin OPD melakukan proses olah data telah sesuai dan mudah dimengerti.

10) Secara keseluruhan, aplikasi yang dibangun sudah baik, sesuai dengan proses manual dan mampu mengumpulkan data statistik sektoral dari organisasi perangkat daerah.

Berdasarkan rangkuman jawaban diatas, maka dapat ditarik kesimpulan bahwa aplikasi pengolahan data statistik sektoral yang dibangun telah memenuhi aspek kegunaan seperti yang ditunjukkan pada poin 1, 2, 3, 4, 5, 6 dan 7 diatas bahwa tujuan, target pengguna, kebutuhan akan data statistik sektoral, mengatasi kendala pada proses manual, kesesuaian dengan proses manual, produk yang dihasilkan dan respon aplikasi terhadap input telah sesuai dan memenuhi fungsi serta kegunaan yang ingin dicapai pada analisis kebutuhan. Selain itu, aspek kemudahan juga telah terpenuhi seperti yang ditunjukkan pada poin 8 dan 9 diatas bahwa kinerja pada saat administrator dan admin OPD melakukan proses olah data telah sesuai dan mudah dimengerti.

\section{Analisis Hasil Pengujian}

Dari hasil pengujian yang telah dilakukan terhadap aplikasi dengan menggunakan metode black-box dan user acceptance test (UAT), maka analisis terhadap hasil pengujian adalah sebagai berikut :

1) Pengujian yang telah dilakukan dengan metode black-box mendapatkan hasil bahwa fungsionalitas dari aplikasi pengolahan data statistik sektoral yang dibangun telah berjalan dengan baik dan sesuai dengan yang diharapkan.

2) Pengujian dengan UAT mendapatkan hasil bahwa secara keseluruhan aplikasi pengolahan data statistik sektoral yang dibangun mendapat nilai baik.

3) Aplikasi mendukung pengumpulan data statistik sektoral dari organisasi perangkat daerah melalui formform yang telah dirancang dan disesuaikan sehingga menghindari kesalahan dalam pengisian data.

4) Aplikasi mendukung publikasi data statistik sektoral yang telah diubah bentuknya oleh administrator (Diskominfo) berdasarkan data yang dikumpulkan dari organisasi perangkat daerah (OPD).

5) Aplikasi mendukung proses unggah dan unduh data statistik sektoral.

6) Diskominfo belum memiliki fasilitas dan sumber daya untuk menjalankan aplikasi secara keseluruhan.
Masih diperlukan waktu untuk proses sosialisasi terhadap organisasi perangkat daerah sehingga memungkinkan untuk dilakukannya penyesuaian terhadap perubahan di masa yang akan datang.

\section{KESIMPULAN}

Setelah dilakukan analisis dan pengujian terhadap Aplikasi Pengolahan Data Statistik Sektoral Provinsi Kalimantan Barat, dapat disimpulkan bahwa :

1) Aplikasi Pengolahan Data Statistik Sektoral Pada Dinas Komunikasi dan Informatika dapat digunakan sebagai wadah atau media untuk mengumpulkan data statistik sektoral dari OPD-OPD di lingkungan pemerintahan Provinsi Kalimantan Barat.

2) Aplikasi Pengolahan Data Statistik Sektoral Pada Dinas Komunikasi dan Informatika dapat digunakan sebagai wadah pengolahan data yaitu, mengubah data statistik berupa angka-angka satuan menjadi data berupa gambar dan file XLS serta publikasi data yaitu, menyajikan dan menyediakan data yang sudah diolah kepada end-user yang terdiri atas OPD-OPD dan pihak terkait di lingkungan pemerintahan provinsi Kalimantan Barat.

3) Berdasarkan studi literatur yang telah dilakukan, ditemukan bahwa terdapat kesesuaian antara sistem yang akan dibangun dan penelitian terkait. Referensi yang digunakan pada penelitian terkait adalah mengenai pengumpulan informasi melalui media komputer dan pengumpulan serta pengolahan data dengan menggunakan aplikasi berbasis web.

4) Setelah melakukan analisis kebutuhan, diperoleh hasil bahwa Dinas Komunikasi dan Informatika yang bertugas sebagai wali data, yaitu memiliki kewenangan untuk mengumpulkan kemudian mempublikasikan data statistik sektoral dilingkungan pemerintah. Untuk menunjang tugas tersebut, maka kemudian dirancang sebuah aplikasi berdasarkan dan disesuaikan dengan sistem yang sedang berlangsung untuk proses pengumpulan, pengolahan dan distribusi data statistik sektoral melalui proses publikasi data.

5) Hasil yang didapatkan dari proses pengumpulan data adalah data statistik sektoral sebanyak 70 jenis data yang berasal dari Seksi Statistik, Bidang Persandian dan Statistik, Dinas Komunikasi dan Informatika. Data statistik sektoral yang didapatkan berbentuk data-data angka yang diklasifikasikan berdasarkan tahun, bulan atau kabupaten/kota.

6) Perancangan Sistem yang dilakukan menggunakan Unified Model Language (UML), struktur antarmuka dan layout. Perancangan yang dilakukan tersebut dapat mendefinisikan jenis pengguna, atribut, operasi dan tampilan antarmuka yang dapat memenuhi tujuan dari sistem yang akan dibangun. 
Pembuatan dan Implementasi Sistem yang telah dilakukan menghasilkan sebuah aplikasi pengolahan data statistik sektoral yang dapat melakukan pengumpulan, pengolahan dan publikasi data statistik sektoral. Aplikasi yang dibangun memiliki 3 level pengguna, yaitu administrator yang berasal dari Diskominfo, admin OPD yang berasal dari organisasi-organisasi perangkat daerah dan guest atau pengguna umum.

7) Pengujian Sistem dilakukan dengan metode BlackBox terhadap menu-menu dan fungsi dari aplikasi mendapatkan hasil bahwa sistem dapat berjalan dengan baik sesuai dengan yang telah direncanakan. Selain itu, untuk menguji penerimaan pengguna dengan menggunakan User Acceptance Testing (UAT) diperoleh hasil bahwa sistem diterima dengan baik oleh pengguna.

8) Analisis hasil dari pengujian terhadap aplikasi pengolahan data statistik sektoral adalah Pengujian yang telah dilakukan dengan metode black-box mendapatkan hasil bahwa fungsionalitas dari aplikasi pengolahan data statistik sektoral yang dibangun telah berjalan dengan baik dan sesuai dengan yang diharapkan. Selain itu, Pengujian dengan kuesioner evaluasi mendapatkan hasil bahwa secara keseluruhan sistem informasi statistik sektoral yang dibangun mendapat nilai baik dan dapat diterima dengan baik oleh pengguna.

9) Kesimpulan yang dapat ditarik dari penelitian yang telah dilakukan adalah Aplikasi Pengolahan Data Statistik Sektoral Pada Dinas Komunikasi dan Informatika Provinsi Kalimantan Barat setelah dilakukan pengujian mendapatkan hasil bahwa aplikasi telah berjalan sesuai dengan perancangan dan dapat diterima dengan nilai baik oleh pengguna.

\section{DAFTAR PUSTAKA}

[1] Sari, Yunita Rizki Intan dan Sulistiadi, Yunarso Anang. 2013. Prototipe Sistem Aplikasi Capi Data Kor Susenas. Skripsi. Sekolah Tinggi Ilmu Statistik.

[2] Kumase, Rivani. 2016. Rancang Bangun Aplikasi Pelaporan Dana Alokasi Khusus Berbasis Web (Studi Kasus : BAPPEDA Provinsi Sulawesi Utara). Skripsi. Universitas Katolik De La Salle Manado.

[3] Peraturan Kepala Badan Pusat Statistik. 2009. Nomor 9 Tahun 2009 Tentang Penyelenggaraan Statistik Sektoral oleh Pemerintah Daerah. Badan Pusat Statistik. Jakarta.

[4] Almuqsitu, Abang Boni, Tursina, dan Sukamto, Anggi Srimurdianti. Rancang Bangun Aplikasi Pelayanan Pelanggan PDAM Tirta Kapuas Berbasis Web. Jurnal Sistem dan Teknologi Informasi (JUSTIN). Vol. 7, No. 1, pp. 13-19, 2019.

[5] Agusvianto, Hendra. Sistem Informasi Inventori Gudang Untuk Mengontrol Persediaan Barang Pada Gudang (Studi Kasus : PT. Alayisis Sidoarjo). Journal Information Engineering and Educational Technology. Vol. 1, No. 1, pp. 40-46, 2017

[6] Mulyani, Sri. 2016. Metode Analisis dan Perancangan Sistem. Bandung: Abdi SisteMatika.

[7] Indrajani. 2015. Database Design (Case Study All in One). Jakarta: PT Elex Media Komputindo.

[8] Sukamto, R. A., dan Shalahudin, M. 2015. Rekayasa Perangkat Lunak Terstruktur Dan Berorientasi Objek. Bandung INFORMATIKA.

[9] Madcoms. 2016. Sukses Membangun Toko Online dengan PHP \& MySQL. Yogyakarta: Andi.

[10] Solichin, Achmad. 2016. Pemrograman Web dengan PHP dan MySQL. Jakarta : Budi Luhur.
[11] Hidayatullah, Priyanto, dan Kawistara, Jauhari Khairul. 2017. Pemrograman WEB. Bandung. Informatika Bandung.

[12] Aminudin. 2015. Cara Efektif Belajar Framework Laravel. Yogyakarta: Lokomedia.

[13] Mustaqbal, M. S., Firdaus, R. F., dan Rahmadi, H. Pengujian Aplikasi Menggunakan Black Box Testing Boundary Value Analysis. Jurnal Ilmiah Teknologi Informasi Terapan. Vol. 1, No. 3, pp. 31-36, 2015.

[14] Prasetya, Irwan Adhi, Tursina, dan Safriadi, Novi. Penerapan Visual Novel Dari Cerita Rakyat Asal Usul Kota Pontianak. Jurnal Sistem dan Teknologi Informasi (JUSTIN). Vol. 1, No. 1, pp. 1-5, 2015.

[15] (2019) SIRUSA (Sistem Informasi Rujukan Statistik) website [Online]. Available: https://sirusa.bps.go.id/sirusa/

[16] Pragestu, Steven, Sujaini Herry, dan Negara, A. B. P. Implementasi Augmented Reality dengan Memanfaatkan GPS Based Tracking pada Sistem Pengenalan Gedung Universitas Tanjungpura. Jurnal Edukasi dan Penelitian Informatika (JEPIN). Vol. 1, No. 2, pp. 122-127, 2015. 